\title{
KETIMPANGAN PEMBANGUNAN DI SULAWESI BARAT
}

\author{
Endriady Edy Abidin*
}

Ahmad Amiruddin*

\author{
* Fakultas Ilmu Sosial dan Ilmu Politik, Universitas Sulawesi Barat \\ Corresponding Email: eea@unsulbar.ac.id
}

\begin{abstract}
ABSTRAK:
Sulawesi Barat merupakan sebuah daerah pemekaran pasca-reformasi dari Sulawesi Selatan. Tujuan pemekaran adalah akselerasi pembangunan. Namun dalam perkembangan sebuah daerah pemekaran, ketimpangan antar-kabupaten dalam provinsi merupakan sangat sering ditemukan. Perbedaan kondisi geografis, alokasi dana, sumberdaya alam, sumberdaya manusia, infrastruktur, dinamika politik dan kebijakan daerah, serta konsentrasi ekonomi yang berbeda mengakibatkan satu daerah lebih maju dibandingkan daerah lainnya. Penelitian ini menggukan metode campuran dalam membangun analisis ketimpangan kabupaten di Sulawesi Barat. Hasil penelitian menunjukkan ketimpangan kabupaten di Sulawesi Barat masuk dalam kategori sedang, yaitu berada pada kisaran di atas 0,35 namun di bawah 0,5. Perbedaan jumlah penduduk, infrastruktur, kondisi geografis, dan sumberdaya alam, serta sumberdaya manusia menjadikan pembangunan antar-kabupaten berbeda satu dengan yang lain. Untuk meningkatkan pertumbuhan ekonomi, pemusatan ekonomi berdasar pada potensi daerah dapat dilakukan.
\end{abstract}

\section{KATA KUNCI:}

Ketimpangan Kabupaten, Pembangunan Daerah, Sulawesi Barat.

\section{A. PENDAHULUAN}

Kesenjangan atau ketimpangan wilayah (regional inequality) menjadi masalah besar bagi Indonesia sejak lama. Problematika yang merupakan warisan kolonial ini (Agusta, 2014:33; Kurniawan, 2017: 64), yang kemudian diteruskan oleh pemerintah pusat setelah revolusi kemerdekaan 1945 (Kahin \& Kahin, 1997:45-46; Kurniawan, 2017: 64), masih menjadi wajah spasial banyak daerah di Nusantara, yang berpengaruh terhadap ruang-ruang kehidupan masyarakatnya. Di masa lalu, letak dan kondisi geografis tidak jarang menjadi kambing hitam. Pola relasi pusat-pinggiran (center-periphery), yang lahir akibat sentralisasi, diskrimasi spasial, dan kebijakan menjadi warna pemerintahan. Setelah kejatuhan Orde Baru, ancaman disintegrasi wilayah menyeruak. Para elit di pusat kekuasaan beralih kepada desentralisasi. Dan Indonesia berubah, dari salah negara paling sentralis di dunia menjadi negara "hampirfederal" (Mietzner, 2014: 45-46).

Desentralisasi pasca-reformasi diharapkan menjadi oase di padang pasir ketimpangan wilayah. Pemekaran wilayah dan penyerahan otoritas yang lebih besar kepada daerah di era 
reformasi dianggap menjadi solusi bagi ketimpangan ini. Daerah lebih mengetahui apa yang mereka butuhkan, demikian logika Jakarta. Dengan alokasi dana dan otonomi yang besar (Mietzner, 2014:54-55), daerah dapat berkembang lebih jauh menurut kebutuhannya sendiri. Desentralisasi juga dianggap akan memberikan reformasi yang lebih luas, termasuk peningkatan kualitas pelayanan publik yang dapat menjangkau lebih banyak masyarakat, meningkatkan respon pemerintah untuk memenuhi aspirasi publik, dan memberdayakan pemerintah sub-nasional agar lebih terlibat dan mengontrol jalannya pelayanan tersebut (Asante \& Ayee, 2007: 327). Lebih jauh, di beberapa ranah kebijakan dan daerah tertentu, desentralisasi meningkatkan performa kebijakan dengan memberikan pemerintah lokal otoritas menyesuaikan tujuan nasional sesuai dengan konteks lokal, dengan menggunakan pengetahuan lokal, keahlian, dan input demokratis dari masyarakat untuk meningkatkan respon tanggap pemerintah (Holzhacker, dkk., 2016: 4).

Terlepas dari tujuan awal yang hendak memberikan ruang pembangunan bagi daerah sesuai dengan konteks lokal, desentralisasi dalam banyak kasus belum mampu memberikan angin perubahan bagi daerah. Beberapa problematika yang inheren dalam konteks daerah semisal perbedaan sumberdaya manusia (SDM), sumberdaya alam (SDM), dan letak geografis serta kemampuan daerah dalam mengelola potensi yang mereka miliki juga menjadi salah satu faktor yang senantiasa menghantui (Brodjonegoro, 2018). Namun tidak jarang prioritas pembangunan yang dilakukan pemerintah provinsi dan pusat turut memberikan andil bagi ketertinggalan satu daerah dibandingkan daerah lainnya. Termasuk ke dalam konteks ini adalah pemerataan pembangunan infrastruktur yang menunjang pertumbuhan ekonomi daerah dan prioritas pembangunan zona-zona ekonomi.

Sulawesi Barat, yang menjadi fokus kajian dalam riset ini, merupakan sebuah daerah pemekaran setelah reformasi dari Sulawesi Selatan. Resmi berdiri pada 2004, provinsi ini, memiliki 6 kabupaten dengan luas wilayah 16.787,18 km² dan total populasi 1.282.162 orang (BPS Provinsi Sulbar, 2017). Untuk jangka waktu yang cukup lama, daerah-daerah yang kini berada berada di bawah Provinsi Sulawesi Barat merupakan daerah tertinggal jika dibandingkan dengan kabupaten lain yang ada di Sulawesi Selatan. Kesenjangan ekonomi dan pembangunan ini yang menjadi alasan utama perjuangan masyarakat di Mamuju, Majene, dan Polewali Mandar untuk membentuk provinsi sendiri setelah jatuhnya kekuasaan sentralistis orde baru yang memungkinkan munculnya reformasi dan desentralisasi yang disahkan melalui Undang Undang Nomor 22 Tahun 1999.

Dalam perkembangan sebuah daerah pemekaran, ketimpangan antar-kabupaten dalam provinsi merupakan sangat sering ditemukan. Perbedaan kondisi geografis, alokasi 
dana, sumberdaya alam, sumberdaya manusia, infrastruktur, dinamika politik dan kebijakan daerah, serta konsentrasi ekonomi yang berbeda mengakibatkan satu daerah lebih maju dibandingkan daerah lainnya. Berdasarkan pada konteks demikian, artikel hendak ini mengangkat tentang ketimpangan pembangunan yang terjadi di provinsi Sulawesi Barat. Artikel ini akan memaparkan ketimpangan seperti apa yang terjadi dalam kaitannya dengan pembangunan di Sulawesi Barat. Pertanyaan penelitian yang hendak dijawab oleh artikel ini adalah "Ketimpangan kabupaten seperti apa yang terdapat di Provinsi Sulawesi Barat?".

\section{B. STUDI KEPUSTAKAAN}

\section{Konsep Ketimpangan Wilayah}

Secara umum, pembangunan dimaknai sebagai upaya berkesinambungan menciptakan keadaan yang dapat menyediakan lebih banyak alternatif yang valid bagi setiap warga negara untuk mencapai aspirasinya yang paling humanistik (Kabul \& Trigunarso, 2017: 29). Lebih jauh, pembangunan bertujuan untuk mewujudkan bangsa yang maju, mandiri, dan sejahtera lahir batin dan masyarakat yang adil dan makmur. Untuk sampai kesana, titik fokus dalam pembangunan diletakkan pada bidang ekonomi yang menjadi motor penggerak. Seiring dengan meningkatnya pembangunan, maka pengelompokan penduduk dan kegiatan perekonomian tercipta. Seiring berjalannya waktu dan tingkat produktivitas yang berbeda antara satu wilayah dengan wilayah yang lain maka terciptalah ketimpangan antar-wilayah (Kabul \& Trigunarso, 2017: 29-30).

Ketimpangan atau kesenjangan wilayah dapat dipahami sebagai kondisi dimana terdapat perbedaan tingkat kesejahteraan dan perkembangan ekonomi antar wilayah (Ratnasari \& Santoso, 2014: 125). Ketimpangan terjadi didominasi oleh perbedaan pertumbuhan ekonomi, kemiskinan, pendidikan, kesehatan, serta rendahnya akses masyarakat terhadap sarana prasarana sosial ekonomi (Basri dalam Ratnasari \& Santoso, 2014: 125). Jika kita mengacu pada teori pembangunan wilayah, maka faktor lain yang juga dominan dalam terciptanya kesenjangan wilayah adalah faktor geografi, sejarah, politik, kebijakan pemerintah, administrasi, sosial dan ekonomi (Murti \& Rustiadi dalam (Kementerian Perencanaan Pembangunan Nasional/Badan Perencanaan Pembangunan Nasional, 2017: 32). Lebih jauh menurut Syafrizal (dalam Hamid, dkk., 2017) terdapat lima faktor yang menjadi penyebab kesenjangan wilayah, yaitu: $a$. Perbedaan kandungan sumber daya alam; $b$. Perbedaan kondisi geografis; $c$. Kurang lancarnya mobilitas barang dan jasa; $d$. Konsentrasi kegiatan ekonomi wilayah; e. Alokasi dana pembangunan antarwilayah. 
Usaha dalam menanggulangi kesenjangan antar-wilayah (kabupaten) secara umum dapat dilakukan oleh pemerintah pusat maupun pemerintah daerah (provinsi dan kabupaten). Dari kacamata pemerintah pusat (Agusta, 2014: viii-ix), perumusan strategi, kebijakan dan program pengurangan ketimpangan pembangunan wilayah perlu didasarkan pada konteks yang tepat, karena kebijakan yang positif di suatu wilayah belum tentu cocok untuk wilayah lainnya. Terdapat beberapa konteks yang ditemukan memengaruhi kebijakan ini. Konteks tersebut berupa ketimpangan global yang terus meningkat sejak Revolusi Industri (1750-1850), diskursus donor untuk pembangunan nasional, kondisi Indonesia sebagai wilayah pasca kolonial, wilayah Indonesia tergolong luas dan berupa kepulauan. Konteks lainnya ialah pandangan statis terhadap suku, agama, ras dan golongan. Konteks lainnya ialah krisis moneter yang masih dirasakan hingga kini, serta perkembangan otonomi daerah.

Sementara dari sudut pandang daerah, keberadaan undang-undang otonomi daerah memberikan berbagai kewenangan yang dapat dieksekusi oleh daerah, termasuk ke dalamnya adalah kreativitas daerah dalam memaksimalkan pengelolaan sumberdaya yang terdapat di daerahnya untuk pembangunan yang sesuai dengan karakteristik daerahnya. Lebih jauh, pelimpahan wewenang ke daerah (desentralisasi) juga memberikan kewenangan bagi pemerintah daerah untuk dapat mengelola wilayah adminitratifnya sesuai dengan potensi yang mereka miliki dan kebutuhan daerah masing-masing. Di sini, daerah juga dituntut agar memiliki inovasi-inovasi yang dapat berkontribusi terhadap pengurangan kesenjangan (Kementerian Perencanaan Pembangunan Nasional/Badan Perencanaan Pembangunan Nasional, 2017: 32-33).

\section{METODE PENELITIAN}

Penelitian merupakan penelitian yang menggabung metode kuantitatif dan kualitatif. Metode kuantitatif digunakan untuk memandang tingkah laku manusia dapat diramal dan realitas sosial; objektif dan dapat diukur. Oleh karena itu, penggunaan penelitian kuantitatif dengan instrumen yang valid dan reliabel serta analisis statistik yang sesuai dan tepat menyebabkan hasil penelitian yang dicapai tidak menyimpang dari kondisi yang sesungguhnya (Yusuf, 2017: 65). Riset kualitatif bertujuan untuk mencari jawaban dengan cara mengeksplorasi dan memahami berbagai macam konteks sosial dan individu atau kelompok yang berlindung di bawah konteks tersebut. Penelitian kualitatif menitikberatkan perhatian pada bagaimana manusia mengatur diri dan konteks di mana ia eksis dan bagaimana mereka, dari konteks tersebut, memahami sekelilingnya melalui simbol, ritual, 
struktur sosial, peranan sosial, dan sebagainya. Hasil penelitian kualitatif bersifat fleksibel dan menggunakan model induktif, berfokus pada pemaknaan individu, dan deskripsi atas kerumitan dari sebuah situasi (Creswell, 2014: 4; Berg, 2001: 4).

Untuk mengukur ketimpangan pembangunan di Sulawesi Barat metode yang digunakan metode indeks Williamson. Pada saat ini ukuran ketimpangan wilayah banyak menggunakan ide-ide dari Jeffrey Williamson yang mendasarkan diri pada teori Kuznet. Williamson menggunakan kaidah statistika tentang nilai tengah, yaitu koefisien variasi (CV). Untuk mengaitkannya dengan kewilayahan, maka koefisiensi variasi tersebut dikaitkan dengan jumlah penduduk (CVs). Perhitungan ini menggunakan model persamaan umum (Agusta, 2014: 196).

Williamson memandang masalah pembangunan wilayah di negara sedang berkembang ialah peningkatan jumlah penduduk yang sangat besar, sehingga hasil-hasil pertumbuhan ekonomi bisa "digerogoti". Analisis diarahkan untuk mengisolasi faktor-faktor penyebab pertumbuhan ekonomi tersebut. Diyakini, setelah pola pertumbuhan tersebut diketahui, maka kebijakan yang sesuai dengan realitas kewilayahan bisa dikembangkan (Agusta, 2014: 196).

Pembangunan perkotaan dalam jangka panjang tergantung dari produktivitas yang dikembangkan. Namun dalam jangka pendek produktivitas tersebut akan ditahan oleh peningkatan kebutuhan perumahan, keterampilan tenaga kerja, lahan perkotaan. Pertumbuhan perkotaan dipengaruhi oleh sembilan faktor, yaitu perubahan harga dalam industri, perubahan produktivitas industri, perubahan harga dalam pertanian, perubahan produktivitas pertanian, pertumbuhan angkatan kerja, akumulasi kapital dalam industri manufaktur, akumulasi kesediaan rumah di perkotaan untuk orang miskin, akumulasi kesediaan rumah di perdesaan untuk orang miskin, dan keterampilan (Agusta, 2014: 196)197.

Selanjutnya Williamson mengemukakan teorinya, bahwa kecenderungan ketimpangan wilayah berbentuk kurva U. Pada awal pembangunan, ketimpangan wilayah cenderung meningkat. Pada perkembangan pembangunan berikutnya mulailah terjadi penurunan ketimpangan wilayah (Agusta, 2014: 197). 
Indeks Williamson mengukur derajat ketimpangan antar wilayah yang didasarkan pada PDRB per kapita dalam kaitannya dengan jumlah penduduk per daerah. Apabila Indeks Williamson mendekati nol, maka ketimpangan pendapatan antar kabupaten/kota rendah juga pertumbuhan ekonomi antar daerah merata. Namun, apabila Indeks Williamson bernilai mendekati satu, maka ketimpangan distribusi pendapatan antar kabupaten/kota tinggi dan mengindikasikan pertumbuhan ekonomi antar daerah tidak merata (Kementerian

$$
\begin{aligned}
& C V_{w}=\frac{\sqrt{\sum(Y i-\bar{y})^{2} f i / n}}{\bar{y}} \\
& \text { Keterangan } \mathrm{CVw}=\text { Indeks Williamson } \\
& \mathrm{fi}=\text { Jumlah penduduk kabupaten/kota ke-i (jiwa) } \\
& \text { = Jumlah penduduk pada wilayah yang lebih luas (jiwa) } \\
& \text { = PDRB per kapita kabupaten/kota ke-i (Rupiah) } \\
& \text { = PDRB per kapita rata-rata pada wilayah yang lebih luas (Rupiah) }
\end{aligned}
$$

Perencanaan Pembangunan Nasional/Badan Perencanaan Pembangunan Nasional, 2017). Adapun rumus dari Indeks Williamson sebagai berikut.

Teori kedua yang digunakan adalah teori cumulative causation berasal dari Gunnar Myrdal. Teori ini memahami kemungkinan tertariknya sumberdaya wilayah tertinggal ke wilayah maju. Oleh karena meyakini potensi kemampuan di wilayah (yang dinamakan tertinggal), maka teori ini menyarankan pendirian kota atau industri di wilayah yang lebih tertinggal (Agusta, 2014: 238). Lebih jauh, menurut Fujita (Fujita, 2007) fokus teori Myrdal adalah pada pembangunan yang berfokus untuk meningkatkan produksi tanpa mengabaikan analisis ekonomi dan non-ekonomi serta memberikan penekanan pada kemungkinan reformasi sosial dengan memperkenalkan kebijakan ekonomi.

\section{PEMBAHASAN}

Di masa lalu, sentralisasi kekuasaan dan ekonomi, diskriminasi spasial, serta kebijakan yang tidak adil menjadi penyebab terjadinya ketimpangan wilayah. Reformasi tahun 1998 memberikan angin segar perubahan bagi daerah dengan memberikan kewenangan bagi daerah untuk mengatur dirinya sendiri termasuk dalam merencanakan pembangunannya sendiri. Cara pandang desentralisasi ini didorong oleh cara pandang neoinstitusional (Lihat Hadiz 2004), sebagai bentuk reorganisasi administrasi dan kewenangan untuk akselerasi pembangunan di tingkat kabupaten/kota. Cara ini dipandang sebagai jalan tengah devolusi otoritas ekonomi dan politik dan ditujukan untuk memunculkan berbagai inisiatif kebijakan yang kreatif dan kontekstual bagi daerah serta mendorong partisipasi publik (Rasyid 2004: 63). 
Model baru ini sangat berbeda dengan sebelumnya, yang sangat sentralistik dan senantiasa mengontrol ketat berbagai sumberdaya, ekonomi dan politik, di semua daerah, dan membawa harapan besar bagi banyak orang di Indonesia terutama orang-orang yang berada di luar Jawa. Bagi orang-orang ini, banyak dari mereka yang tidak benar-benar merasakan masa pembangunan Orde Baru, kecuali korupsi, kolusi dan nepotisme yang diturunkan dari pusat (Sulistiyanto dan Erb dalam Erb dan Sulistiyanto 2005: 1). Undangundang Otonomi Daerah no. 22/1999, yang menjadi aturan main baru tersebut, membatasi banyak dari otoritas pemerintah pusat sebelumnya dan memindahkannya ke tangan pemerintah kabupaten/kota. Otoritas politik lokal yang tadinya dikontrol secara ketat oleh Jakarta, kini berpindah ke tangan orang-orang lokal. Posisi politik orang lokal di Dewan Perwakilan Rakyat Daerah juga meningkat dan kemudian mengontrol eksekutif lokal (Pratikno 2005: 20).

Salah satu wilayah yang mendapat blessing reformasi adalah Sulawesi Barat. Provinsi ini berdiri pada tahun 2004 dan merupakan pemekaran dari Sulawesi Selatan. Untuk jangka waktu yang cukup lama, daerah-daerah yang kini berada berada di bawah Provinsi Sulawesi Barat merupakan daerah tertinggal jika dibandingkan dengan kabupaten lain yang ada di Sulawesi Selatan. Kesenjangan ekonomi dan pembangunan ini yang menjadi alasan utama perjuangan masyarakat di Mamuju, Majene, dan Polewali Mandar untuk membentuk provinsi sendiri setelah jatuhnya kekuasaan sentralistis orde baru yang memungkinkan munculnya reformasi dan desentralisasi yang disahkan melalui Undang Undang Nomor 22 Tahun 1999.

Namun terlepas dari tujuan awalnya, sesuai dengan tujuan reformasi Indonesia, Sulawesi Barat yang kini berjumlah enam kabupaten, tentunya memiliki kemajuan pembangunan yang berbeda-beda sesuai dengan dinamika politik lokal, kebijakan pemerintah daerah, sumberdaya alam dan manusia serta potensi ekonomi lainnya yang dimiliki oleh masing-masing kabupaten. Berbagai faktor ini yang menentukan pertumbuhan ekonomi dan kemajuan sebuah daerah. Namun dalam perkembangannya, sesuai dengan kondisi yang telah disebutkan sebelumnya, pembangunan ekonomi tiap daerah bervariasi dan menyebabkan ketimpangan pembangunan di antara kabupaten. Terdapat kabupaten dengan pertumbuhan ekonomi yang cukup tinggi sementara kabupaten lain jauh tertinggal di belakang. Umumnya yang berperan dalam satu pertumbuhan yang tinggi adalah adanya sektor unggulan yang berkontribusi besar terhadap pertumbuhan ekonomi dan pembangunan. 
Dampak yang mungkin timbul dari dari perbedaan kemampuan satu daerah dengan daerah lainnya adalah kapabilitas dalam melaksanakan pembangunan menjadi berbeda satu dengan yang lain. Daerah yang yang dapat memaksimalkan potensi unggulannya akan menjadi daerah maju sedangkan daerah yang tidak memiliki sektor unggulan atau kebijakan ekonominya keliru akan menjadi daerah tertinggal. Perbedaan pembangunan tentu saja akan berdampak langsung kepada masyarakat. Daerah maju memiliki tingkat kesejahteraan yang jauh lebih baik dibandingkan daerah tertinggal. Ketimpangan pembangunan juga akan berdampak pada strategi pembangunan yang dilakukan masing-masing daerah.

\section{Indeks Williamson Ketimpangan Sulawesi Barat}

Untuk mengevaluasi perkembangan pembangunan di Sulawesi Barat penelitian menggunakan ini indeks Williamson. Sebelum melakukan kalkulasi, terlebih dahulu dijabarkan produk domestik regional bruto (PDRB) yang datanya berasal dari Biro Pusat Statistik (BPS). Selanjutnya dijabarkan jumlah populasi dalan rentang waktu antara 2005 dan 2019.

\section{Tabel 1}

\section{PDRB Per Kapita berdasarkan harga konstan Kabupaten di Sulawesi Barat} tahun 2005 - 2019

\begin{tabular}{|c|c|c|c|c|c|c|c|c|c|c|c|c|c|c|c|}
\hline \multirow[t]{3}{*}{ No } & \multirow[t]{3}{*}{ Kabupaten } & \multicolumn{14}{|c|}{ PDRB Per Kapita Berdasarkan Harga Konstan (Juta Rupiah) } \\
\hline & & \multicolumn{9}{|c|}{2000} & \multicolumn{5}{|c|}{2010} \\
\hline & & 2005 & 2006 & 2007 & 2008 & 2009 & 2010 & 2011 & 2012 & 2013 & 2014 & 2015 & 2016 & 2017 & 2018 \\
\hline 1 & Mamuju & - & $\begin{array}{l}888 . \\
648, \\
69\end{array}$ & $\begin{array}{l}1.02 \\
9.69 \\
4,03\end{array}$ & $\begin{array}{l}1.14 \\
8.99 \\
3,52\end{array}$ & \begin{tabular}{l|}
1.243 \\
$.844,8$ \\
3.
\end{tabular} & $\begin{array}{l}1.37 \\
5.66 \\
2,80\end{array}$ & $\begin{array}{l}1.53 \\
4.03 \\
5,28\end{array}$ & $\begin{array}{l}1.71 \\
0.17 \\
0\end{array}$ & $\begin{array}{l}1.36 \\
1.58 \\
0\end{array}$ & $\begin{array}{l}23.2 \\
30.0 \\
00\end{array}$ & $\begin{array}{l}24.3 \\
60.0 \\
00\end{array}$ & $\begin{array}{l}33.3 \\
90.0 \\
00\end{array}$ & $\begin{array}{l}26.8 \\
20.0 \\
00\end{array}$ & $\begin{array}{l}26.9 \\
60.0 \\
00\end{array}$ \\
\hline 2 & $\begin{array}{l}\text { Mamuju } \\
\text { Tengah* }\end{array}$ & & & & & & & & & $\begin{array}{l}504 . \\
070\end{array}$ & $\begin{array}{l}14.3 \\
40.0 \\
00\end{array}$ & $\begin{array}{l}14.8 \\
00.0 \\
00\end{array}$ & $\begin{array}{l}20.0 \\
00.0 \\
00\end{array}$ & $\begin{array}{l}15.7 \\
60.0 \\
00\end{array}$ & $\begin{array}{l}22.7 \\
10.0 \\
00\end{array}$ \\
\hline 3 & $\begin{array}{l}\text { Pasangkayu } \\
* *\end{array}$ & - & $\begin{array}{l}423 . \\
893, \\
21\end{array}$ & $\begin{array}{l}455 . \\
444, \\
04\end{array}$ & $\begin{array}{l}489 . \\
969 \\
84\end{array}$ & $\begin{array}{l}532.4 \\
65,54\end{array}$ & $\begin{array}{l}711 . \\
237 \\
26\end{array}$ & $\begin{array}{l}826 . \\
012, \\
50\end{array}$ & $\begin{array}{l}933 . \\
240\end{array}$ & $\begin{array}{l}1.01 \\
3.08 \\
0\end{array}$ & $\begin{array}{l}36.2 \\
80.0 \\
00\end{array}$ & $\begin{array}{l}38.5 \\
80.0 \\
00\end{array}$ & $\begin{array}{l}49.9 \\
70.0 \\
00\end{array}$ & $\begin{array}{l}40.4 \\
10.0 \\
00\end{array}$ & $\begin{array}{l}56,7 \\
90.0 \\
00\end{array}$ \\
\hline 4 & Majene & - & $\begin{array}{l}455 . \\
049, \\
92\end{array}$ & $\begin{array}{l}475 . \\
962 \\
73\end{array}$ & $\begin{array}{l}510 . \\
134, \\
08\end{array}$ & \begin{tabular}{l|}
541. \\
610, \\
76
\end{tabular} & $\begin{array}{l}611 . \\
588 \\
41\end{array}$ & $\begin{array}{l}657 . \\
603 \\
19\end{array}$ & $\begin{array}{l}703 . \\
900\end{array}$ & $\begin{array}{l}743 . \\
050\end{array}$ & $\begin{array}{l}16.5 \\
70.0 \\
00\end{array}$ & $\begin{array}{l}17.2 \\
20.0 \\
00\end{array}$ & $\begin{array}{l}22.8 \\
50.0 \\
00\end{array}$ & $\begin{array}{l}18.8 \\
50.0 \\
00\end{array}$ & $\begin{array}{l}26.9 \\
60.0 \\
00\end{array}$ \\
\hline 5 & $\begin{array}{l}\text { Polewali } \\
\text { Mandar }\end{array}$ & - & $\begin{array}{l}1.06 \\
7.61 \\
854\end{array}$ & $\begin{array}{l}1.13 \\
6.04 \\
3,82\end{array}$ & $\begin{array}{l}1.22 \\
3.50 \\
6,70\end{array}$ & $\begin{array}{l}1.28 \\
3.75 \\
1,47\end{array}$ & $\begin{array}{l}1.42 \\
8.76 \\
7,95\end{array}$ & $\begin{array}{l}1.56 \\
7.12 \\
8,89\end{array}$ & $\begin{array}{l}1.72 \\
2.37 \\
0\end{array}$ & $\begin{array}{l}1.86 \\
0.60 \\
0\end{array}$ & $\begin{array}{l}16.2 \\
20.0 \\
00\end{array}$ & $\begin{array}{l}17.2 \\
10.0 \\
00\end{array}$ & $\begin{array}{l}24.2 \\
60.0 \\
00\end{array}$ & $\begin{array}{l}19.3 \\
10.0 \\
00\end{array}$ & $\begin{array}{l}28.5 \\
60.0 \\
00\end{array}$ \\
\hline 6 & Mamasa & - & $\begin{array}{l}459 . \\
207, \\
76\end{array}$ & $\begin{array}{l}477, \\
285, \\
57\end{array}$ & $\begin{array}{l}517 . \\
6592 \\
7\end{array}$ & \begin{tabular}{l|}
540. \\
0615 \\
0
\end{tabular} & $\begin{array}{l}612 . \\
181, \\
69\end{array}$ & $\begin{array}{l}657 . \\
189, \\
80\end{array}$ & $\begin{array}{l}700 . \\
680\end{array}$ & $\begin{array}{l}737 . \\
680\end{array}$ & $\begin{array}{l}11.0 \\
20.0 \\
00\end{array}$ & $\begin{array}{l}11.6 \\
10.0 \\
00\end{array}$ & $\begin{array}{l}15.0 \\
70.0 \\
00\end{array}$ & $\begin{array}{l}12.7 \\
20.0 \\
00\end{array}$ & $\begin{array}{l}17,3 \\
60.0 \\
00\end{array}$ \\
\hline & $\begin{array}{l}\text { Sulawesi } \\
\text { Barat }\end{array}$ & \begin{tabular}{|l|}
3.127 \\
035
\end{tabular} & $\begin{array}{l}.33 \\
8.75 \\
4,32\end{array}$ & $\begin{array}{l}3.56 \\
7.81 \\
6,3\end{array}$ & $\begin{array}{l}3.75 \\
1.51 \\
4\end{array}$ & $\begin{array}{l}3,91 \\
8,93 \\
0\end{array}$ & $\begin{array}{l}4.09 \\
5.79 \\
7\end{array}$ & $\begin{array}{l}4.40 \\
0.00 \\
0\end{array}$ & $\begin{array}{l}4.68 \\
0.00 \\
0\end{array}$ & $\begin{array}{l}4.95 \\
0.00 \\
0\end{array}$ & $\begin{array}{l}19.2 \\
10.0 \\
00\end{array}$ & $\begin{array}{l}20.2 \\
60.0 \\
00\end{array}$ & $\begin{array}{l}27.5 \\
40.0 \\
00\end{array}$ & $\begin{array}{l}22,0 \\
60.0 \\
00\end{array}$ & $\begin{array}{l}23.0 \\
00.0 \\
00\end{array}$ \\
\hline
\end{tabular}



Tabel 2

Jumlah Populasi Kabupaten di Sulawesi Barat

tahun 2005 - 2019

\begin{tabular}{|c|c|c|c|c|c|c|c|c|c|c|c|c|c|c|c|}
\hline \multirow[t]{2}{*}{ No } & \multirow[t]{2}{*}{ Kabupaten } & \multicolumn{14}{|c|}{ Tahun (Jiwa) } \\
\hline & & 2005 & 2006 & 2007 & 2008 & 2009 & 2010 & 2011 & 2012 & 2013 & 2014 & 2015 & 2016 & 2017 & 2018 \\
\hline 1 & Mamuju & $\begin{array}{l}283 . \\
528\end{array}$ & $\begin{array}{l}284 . \\
331\end{array}$ & $\begin{array}{l}296 . \\
828\end{array}$ & $\begin{array}{l}305 . \\
473\end{array}$ & $\begin{array}{l}315 . \\
053\end{array}$ & $\begin{array}{l}336 . \\
973\end{array}$ & $\begin{array}{l}349 . \\
571\end{array}$ & $\begin{array}{l}358 . \\
527\end{array}$ & $\begin{array}{l}252 . \\
262\end{array}$ & $\begin{array}{l}258 . \\
984\end{array}$ & $\begin{array}{l}265 . \\
800\end{array}$ & $\begin{array}{l}272 . \\
260\end{array}$ & $\begin{array}{l}279 . \\
390\end{array}$ & $\begin{array}{l}286 . \\
390\end{array}$ \\
\hline 2 & $\begin{array}{l}\text { Mamuju } \\
\text { Tengah* }\end{array}$ & & & & & & & & & $\begin{array}{l}115 . \\
188\end{array}$ & $\begin{array}{l}118 . \\
188\end{array}$ & $\begin{array}{l}121 . \\
380\end{array}$ & $\begin{array}{l}124 . \\
380\end{array}$ & $\begin{array}{l}127 . \\
600\end{array}$ & $\begin{array}{l}130 . \\
830\end{array}$ \\
\hline 3 & $\begin{array}{l}\text { Pasangkayu } \\
\text { ** }\end{array}$ & $\begin{array}{c}96.7 \\
32\end{array}$ & $\begin{array}{l}98.0 \\
35\end{array}$ & $\begin{array}{l}101 . \\
615\end{array}$ & $\begin{array}{l}106 . \\
949\end{array}$ & $\begin{array}{l}111 . \\
150\end{array}$ & $\begin{array}{l}134 . \\
369\end{array}$ & $\begin{array}{l}142 . \\
075\end{array}$ & $\begin{array}{l}145 . \\
502\end{array}$ & $\begin{array}{l}148 . \\
129\end{array}$ & $\begin{array}{l}152 . \\
505\end{array}$ & $\begin{array}{l}156 . \\
460\end{array}$ & $\begin{array}{l}161 . \\
030\end{array}$ & $\begin{array}{l}165 . \\
230\end{array}$ & $\begin{array}{l}286 . \\
390\end{array}$ \\
\hline 4 & Majene & $\begin{array}{l}131 . \\
717\end{array}$ & $\begin{array}{l}131 . \\
977\end{array}$ & $\begin{array}{l}133 . \\
232\end{array}$ & $\begin{array}{l}133 . \\
183\end{array}$ & $\begin{array}{l}133 . \\
296\end{array}$ & $\begin{array}{l}51 . \\
107\end{array}$ & $\begin{array}{l}153 . \\
869\end{array}$ & $\begin{array}{l}58 . \\
036\end{array}$ & $\begin{array}{l}158 . \\
890\end{array}$ & $\begin{array}{l}131 . \\
162\end{array}$ & $\begin{array}{l}163 . \\
900\end{array}$ & $\begin{array}{l}166 \\
400\end{array}$ & $\begin{array}{l}169 . \\
070\end{array}$ & $\begin{array}{l}171 . \\
270\end{array}$ \\
\hline 5 & $\begin{array}{l}\text { Polewali } \\
\text { Mandar }\end{array}$ & $\begin{array}{l}363 . \\
418\end{array}$ & $\begin{array}{l}356 . \\
391\end{array}$ & $\begin{array}{l}361 . \\
202\end{array}$ & $\begin{array}{l}361 . \\
342\end{array}$ & $\begin{array}{l}362 . \\
106\end{array}$ & $\begin{array}{l}396 . \\
120\end{array}$ & $\begin{array}{l}401 . \\
272\end{array}$ & $\begin{array}{l}409 . \\
648\end{array}$ & $\begin{array}{l}412 . \\
122\end{array}$ & $\begin{array}{l}417 . \\
472\end{array}$ & $\begin{array}{l}422 . \\
790\end{array}$ & $\begin{array}{l}427 . \\
480\end{array}$ & $\begin{array}{l}432 . \\
690\end{array}$ & $\begin{array}{l}437 . \\
660\end{array}$ \\
\hline 6 & Mamasa & $\begin{array}{l}121 . \\
448\end{array}$ & $\begin{array}{l}121 . \\
921\end{array}$ & $\begin{array}{l}123 . \\
786\end{array}$ & $\begin{array}{l}125 . \\
309\end{array}$ & $\begin{array}{l}126 . \\
134\end{array}$ & $\begin{array}{l}140 . \\
082\end{array}$ & $\begin{array}{l}142 . \\
416\end{array}$ & $\begin{array}{l}146 . \\
292\end{array}$ & $\begin{array}{l}147 . \\
660\end{array}$ & $\begin{array}{l}149 . \\
809\end{array}$ & $\begin{array}{l}151 . \\
830\end{array}$ & $\begin{array}{l}153 . \\
900\end{array}$ & $\begin{array}{l}156 . \\
970\end{array}$ & $\begin{array}{l}159 . \\
200\end{array}$ \\
\hline & $\begin{array}{l}\text { Sulawesi } \\
\text { Barat }\end{array}$ & $\begin{array}{l}996 . \\
843\end{array}$ & $\begin{array}{l}992 . \\
656\end{array}$ & $\begin{array}{l}1.01 \\
6.66 \\
3\end{array}$ & $\begin{array}{l}1.03 \\
2.25 \\
6\end{array}$ & $\begin{array}{l}1.04 \\
7.73 \\
9\end{array}$ & $\begin{array}{l}1.15 \\
8.65 \\
1\end{array}$ & $\begin{array}{l}1.18 \\
9.20 \\
3\end{array}$ & $\begin{array}{l}1.21 \\
8.00 \\
5\end{array}$ & $\begin{array}{l}1.23 \\
4.25 \\
1\end{array}$ & $\begin{array}{l}125 . \\
890\end{array}$ & $\begin{array}{l}1.28 \\
2.60\end{array}$ & $\begin{array}{l}1.30 \\
6.48 \\
0\end{array}$ & $\begin{array}{l}1.33 \\
0.96 \\
0\end{array}$ & $\begin{array}{l}1.35 \\
5.55 \\
0\end{array}$ \\
\hline
\end{tabular}

Sumber: Biro Pusat Statistik Provinsi Sulawesi Barat

Keterangan:* Mamuju Tengah terbentuk pada tahun 2012, sehingga data yang diperoleh dimulai dari tahun

tersebut. Untuk Mamuju, per-2012 jumlahnya dikurangi penduduk Mamuju Tengah.

** Pasangkayu adalah nama baru dari kabupaten Mamuju Utara.

Berdasarkan pada produk domestik regional bruto berbasis harga konstan di atas dan populasi di atas maka diperoleh indeks Williamson ketimpangan di Sulawesi Barat adalah sebagai berikut:

Tabel 3

Indeks Williamson Ketimpangan Sulawesi Barat

\begin{tabular}{|c|c|c|}
\hline No. & Tahun & Indeks Williamson \\
\hline 1 & 2005 & 0,139 \\
\hline 2 & 2006 & 0,151 \\
\hline 3 & 2007 & 0,154 \\
\hline 4 & 2008 & - \\
\hline 5 & 2009 & - \\
\hline 6 & 2010 & 0,320 \\
\hline 7 & 2011 & 0,335 \\
\hline 8 & 2012 & 0,342 \\
\hline 9 & 2013 & 0,375 \\
\hline 10 & 2014 & 0,376 \\
\hline 11 & 2015 & 0,361 \\
\hline 12 & 2016 & \\
\hline
\end{tabular}




\begin{tabular}{|c|c|c|}
\hline 13 & 2017 & 0,359 \\
\hline 14 & 2018 & 0,355 \\
\hline
\end{tabular}

Sumber: Data diolah dari berbagai sumber.

Pada tabel olahan di atas, tidak tersedia data yang secara spesifik membahas tahun 2005, 2009, dan 2010. Untuk data tahun 2006 hingga 2008 menggunakan harga konstan tahun 2000. Untuk 2011-2018 menggunakan harga konstan 2010. Perhitungan 2011 dan 2012 tidak menyertakan kabupaten Mamuju Tengah yang baru terbentuk pada akhir 2012. Mamuju Tengah tampil dalam data 2013 dan setelahnya.

Kondisi dalam satu sewindu terakhir, dari analisis williamson ditemukan bahwa terdapat fluktuasi dalam indeks ketimpangan pembangunan. Tahun 2011 indeks williamson Sulawesi Barat adalah 0,320. Kondisi demikian terus bertambah hingga tahun 2015 dengan indeks 3,76. Namun tahun 2016, indeks ketimpangan menurun dan tren demikian terus berlanjut hingga 2018.

Berdasarkan pada data di atas, kriteria untuk menentukan tingkat kesenjangan adalah sebagai berikut (Anggraeni dalam Iskandar dan Saragih, 2018: 43):

\begin{tabular}{|l|l|}
\hline IW $<0,35$ & Kesenjangan ekonomi taraf rendah \\
\hline $0,35<$ IW $<0,5$ & Kesenjangan ekonomi taraf sedang \\
\hline IW $>0,5$ & Kesenjangan ekonomi taraf tinggi \\
\hline
\end{tabular}

Berdasarkan pada kategorisasi di atas, maka pertambahan tingkat ketimpangan dan penurunannya setelah 2015 termasuk dalam kategori taraf sedang. Adapun yang tertinggi adalah pada tahun 2015 dengan indeks 0,376 yang mana juga masuk kategori sedang karena di bawah 0,5 dan di atas dari 0,35 .

Meskipun terdapat penurunan dalam indeks ketimpangan, ketimpangan merupakan sebuah akumulasi dari konsentrasi kegiatan ekonomi yang tidak setara antara satu daerah dengan daerah lainnya. Terdapat daerah yang memiliki pertumbuhan ekonomi yang sangat tinggi seperti di Mamuju Utara, dikarenakan produksi perkebunan sawitnya, namun terdapat pula daerah seperti Majene yang pertumbuhan ekonomi lebih tertinggal dari daerah lainnya di Sulawesi Barat. Faktor yang terakhir ini disebabkan kondisi geografis yang tidak sesubur kabupaten lainnya, sehingga tidak menunjang untamanya kegiatan pertanian yang masih menjadi primadona di Sulawesi Barat.

Hal yang patut diperhatikan selanjutnya oleh pemerintah Provinsi Sulawesi Barat adalah pembangunan sumberdaya manusia dan bidang kesehatan. Masih kurangnya tenaga 
kesehatan di Provinsi ini tentunya berpengaruh besar terhadap sumberdaya manusia. Demikian juga dengan pendidikan. Kedua faktor ini banyak berperan penting dalam menunjang pertumbuhan ekonomi yang nantinya akan membantu mengatasi ketimpangan pembangunan antar-kabupaten di Sulawesi Barat.

\section{Pembagian Fokus Pembangunan}

Sulawesi Barat, hingga saat ini, masih bergantung pada sektor yang mengandalkan sumberdaya alam semisal pertanian, perkebunan, kehutanan, perburuan, dan perikanan. Data BPS (2019) menyebutkan sektor ini, mempekerjakan 323.280 orang yang merupakan sektor penyerap tenaga kerja terbesar di Sulawesi Barat. Sektor yang lain semisal jasa mempekerjakan 205.574 tenaga kerja. Sektor industri merupakan sektor yang memiliki tenaga kerja paling rendah dengan jumlah 90.541. Yang kemudian menjadi masalah bagi sektor yang pertama adalah kebanyakan dari pekerja sektor ini berpendidikan sekolah dasar (sebanyak 217.586 jiwa). Dan hanya 5.539 yang berpendidikan perguruan tinggi. Pendidikan yang rendah tidak jarang merupakan batu sandungan bagi produktivitas ekonomi.

Rendahnya pendidikan di sektor primadona Sulbar ini, menjadikan banyak potensi tidak termasimalkan. Salah satu yang mungkin tergambar jelas adalah sektor perikanan. Sulawesi Barat memiliki luas laut $22.012 \mathrm{~km} 2$ dan panjang garis pantai mencapai 617,5 km dengan potensi kelautan dan perikanan yang sangat besar. Potensi perikanan tangkap mencapai 1,02 juta ton per tahun dengan pemanfaatan baru sekitar 64,3 ribu ton. Sedangkan potensi perikanan budidaya mencapai 74.300 hektare, dengan pemanfaatan baru sekitar 24,8 ribu hektare dengan volume produksi tahun 2016 mencapai 121.650 ton (MedanBisnis, 2017). Rendahnya tingkat pendidikan merupakan kendala dalam pembangunan sektor perikanan yang mengakibatkan keterbatasan dalam proses adopsi teknologi, penerimaan dan penyebaran informasi, kesadaran menjaga kelestarian lingkungan dan kualitas kesehatan, dan kemampuan mengakses permodalan (Zainal, 2013:51).

Kendala terbesar di Sulawesi Barat bagi pembangunan dan pertumbuhan ekonomi adalah rendah indeks pembangunan manusia (IPM). Dari enam kabupaten, IPM tertinggi terdapat di kabupaten Mamuju. Mamuju, yang juga merupakan ibukota Sulawesi Barat lebih cepat kemajuannya dibandingkan daerah lain karena faktor ibukota yang menjadikannya tumbuh lebih cepat, dengan dukungan infrastruktur yang cukup memadai. Faktor lainnya adalah Mamuju juga salah satu penghasil kelapa sawit terbesar di Sulawesi Barat, walaupun belakangan ini mengalami kendala diakibatkan oleh larangan impor Uni-Eropa. IPM terendah di Sulawesi Barat terdapat di kabupaten Polewali Mandar. IPM Polewali Mandar 
hanya 62,35 di bawah level Papua Barat dan di atas Papua yang merupakan Provinsi dengan IPM terendah di Indonesia. Dibandingkan level nasional, 71,39, IPM menjadi pekerjaan rumah besar bagi kabupaten ini. Polewali Mandar yang juga merupakan kabupaten dengan penduduk terbanyak di Sulbar sekaligus juga kabupaten yang most improved IPM-nya antara tahun 2013 - 2017 (BPS, 2019). Kabupaten dengan IPM terendah kedua adalah kabupaten Mamasa yang juga paling sedikit peningkatan IPMnya dalam rentang waktu 2013 - 2017. Dari 6 kabupaten Sulbar, tiga berada di bawah rerata provinsi $(64,30)$, tiga lainnya berperforma lebih dari rerata provinsi meski masih jauh di bawah rerata nasional.

Rendahnya IPM Polewali Mandar dan Mamasa, cenderung diakibatkan karena kedua kabupaten ini masih relatif lebih tertinggal dibandingkan kabupaten-kabupaten yang tinggi pertumbuhan ekonominya seperti Mamuju dan Mamuju Utara. Terlepas dari adanya sentra ekonomi besar seperti yang terdapat di kecamatan Wonomulyo, driver ekonomi Polewali Mandar utamanya terdapat di sektor pertanian, perkebunan, dan perikanan yang belum cukup mampu mempercepat pertumbuhan ekonomi kabupaten ini. Salah satu primadona sektor perkebunan Polewali yaitu kakao juga menurun. Hal ini disebabkan oleh masih tingginya tingkat serangan hama dan penyakit serta produktivitas tanaman yang semakin turun akibat tanaman berumur tua.

Kabupaten lain yang juga relatif tertinggal adalah Mamasa. Rendahnya produk domestrik regional bruto yang dimiliki oleh Mamasa karena terbatasnya aktivitas yang dapat merangsang pertumbuhan ekonomi lebih cepat. Sektor ekonomi utama di Mamasa adalah pertanian dan perkebunan serta sektor jasa. Faktor infrastruktur juga menjadi kendala besar di kabupaten ini di samping sumberdaya manusia yang jauh lebih sedikit dibandingkan beberapa kabupaten tetangganya. Penduduk Mamasa hanya berjumlah 159.200, dan tercatat sebagai ketiga terendah di Sulawesi Barat. Dengan kondisi alam yang indah, Mamasa sebenarnya dapat berkembang menjadi sebuah daerah wisata seperti halnya Tana Toraja di Sulawesi Selatan. Kondisi geografisnya juga memungkinkan perkebunan kopi yang lebih luas. Mamasa dikenal sebagai penghasil kopi namun selama ini produksi kopinya belum seterkenal kopi Enrekang atau Toraja. Potensi ini yang belum tergarap secara maksimal, padahal fokus konsentrasi ekonomi ini dapat mendorong peningkatan PDRB daerah.

Kabupaten Majene juga termasuk salah satu yang relatif tertinggal dibandingkan Kabupaten tetangganya di utara. Kabupaten ini merupakan kabupaten yang luas wilayahnya paling kecil di Sulbar (total hanya 5,64 persen atau 947,84 km²), wilayahnya juga tidak sesubur daerah lain. Sektor ekonomi utama di Majene adalah sektor pertanian, Kehutanan, Perburuan, dan Perikanan. Sektor ini mempekerjakan 30.492 orang tenaga kerja. Sumberdaya manusia 
adalah salah satu masalah besar di kabupaten ini. Data BPS (2017) menyebutkan dari total 166.397 penduduk pada tahun 2016, terdapat 33.634 jiwa yang tidak bersekolah atau tamat $\mathrm{SD}$, yang merupakan kategori terbesar dari dalam klasifikasi pendidikan populasi Majene. Luas daerah yang kecil dan kondisi alamnya serta kualitas sumberdaya manusia yang tergolong rendah menjadikan PDRB kabupaten juga rendah. Namun konsensus pendirian provinsi Sulawesi Barat pada tahun 2004, salah satunya adalah menjadikan Majene sebagai kota pendidikan untuk Sulbar. Berdirinya berbagai institusi pendidikan di kabupaten ini diharapkan menjadi salah pendukung perkembangan daerah ini ke depannya.

Kabupaten termuda di Sulbar adalah kabupaten Mamuju Tengah. Kabupaten ini merupakan pemekaran dari kabupaten Mamuju pada tahun 2012. Kabupaten ini masih tertinggal dibandingkan yang lain dikarena usianya yang tergolong muda selain jumlah sumberdaya manusia yang paling sedikit (130.830 jiwa). Namun kabupaten ini memiliki kesempatan yang besar untuk menjadi sentra perkebunan mengingat jumlah wilayah yang cukup memberi peluang untuk pengembangan sektor perkebunan ke depannya.

Pertumbuhan ekonomi Sulawesi Barat yang cukup tinggi (6,23 persen) serta perhatian pemerintah pusat kepada daerah ini, mengingat akan menjadi pintu gerbang ke ibukota baru Indonesia di Kalimantan Timur, menjadikan Sulawesi Barat daerah yang akan terus berkembang. Yang penting menjadi perhatian di provinsi ini khususnya adalah indeks pembangunan manusia yang masih rendah. Pembangunan infrastuktur yang menunjang pertumbuhan ekonomi terus didorong. Dan yang terpenting adalah adalah pengembangan sektor-sektor yang seharusnya menjadi primadora konsentrasi ekonomi semisal sektor kelautan, perkebunan kopi, dan revitalisasi perkebunan dapat membantu pertumbuhan ekonomi kabupaten-kabupaten di Sulawesi Barat.

\section{E. DAFTAR PUSTAKA}

Acemoglu, D. \& Robinson, J., 2017. Mengapa Negara Gagal. Jakarta: Elex Media.

Agusta, I., 2014. Ketimpangan Wilayah dan Kebijakan Pembangunan di Indonesia. Jakarta: Yayasan Pustaka Obor Indonesia.

Asante, F. \& Ayee, J., 2007. Decentralization and Poverty Reduction. In: E. Isser \& R. Kanbur, eds. The Economy of Ghana: Analytical Perspectives on Stability, Growth, E Poverty. Oxford: James Currey Ltd, pp. 325-347.

Bakri, Syafrizal \& Aimon, H., 2015. Analisis Ketimpangan Pembangunan Antar Kabupaten/Kota Di Sumatera Barat Dan Kebijakan Penanggulannya. Jurnal Kajian Ekonomi, 04(07). 
Berg, B., 2001. Qualitative Research Methods for the Social Sciences. .. Needham Heights, MA: Allyn and Bacon.

BPS Sulawesi Barat, 2006. Sulawesi Barat dalam Angka 2005/2006. Mamuju: BPS Provinsi Sulawesi Barat.

BPS Sulawesi Barat, 2007. Sulawesi Barat dalam Angka 2007. Mamuju: BPS Provinsi Sulawesi Barat.

BPS Sulawesi Barat, 2008. Sulawesi Barat dalam Angka 2008. Mamuju: BPS Provinsi Sulawesi Barat.

BPS Sulawesi Barat, 2009. Sulawesi Barat dalam Angka 2009. Mamuju: BPS Provinsi Sulawesi Barat.

BPS Sulawesi Barat, 2010. Sulawesi Barat dalam Angka 2010. Mamuju: BPS Provinsi Sulawesi Barat.

BPS Sulawesi Barat, 2012. Sulawesi Barat dalam Angka 2012. Mamuju: BPS Provinsi Sulawesi Barat.

BPS Sulawesi Barat, 2013. Sulawesi Barat dalam Angka 2013. Mamuju: BPS Provinsi Sulawesi Barat.

BPS Sulawesi Barat, 2014. Sulawesi Barat dalam Angka 2014. Mamuju: BPS Provinsi Sulawesi Barat.

BPS Sulawesi Barat, 2015. Sulawesi Barat dalam Angka 2015. Mamuju: BPS Provinsi Sulawesi Barat.

BPS Sulawesi Barat, 2016. Provinsi Sulawesi Barat Dalam Angka 2016. Mamuju: BPS Provinsi Sulawesi Barat.

BPS Sulawesi Barat, 2017. Provinsi Sulawesi Barat dalam Angka 2017. Mamuju: BPS Provinsi Sulawesi Barat.

BPS Sulawesi Barat, 2018. Provinsi Sulawesi Barat dalam Angka 2018. Mamuju: BPS Sulawesi Barat.

BPS Sulawesi Barat, 2019. Provinsi Sulawesi Barat dalam Angka 2019, Mamuju: BPS Sulawesi Barat.

Brodjonegoro,

B., 2018. Media Indonesia. [Online]

Available at: http://mediaindonesia.com/read/detail/158797-memangkaskesenjangan-antarwilayah-untuk-pembangunan-indonesia

[Diakses 21 April 2019].

Creswell, J., 2014. Research Design. Thousand Oaks, California: Sage. 
Dewi, I. A. I. U., Budhi , M. K. S. \& Sudirman, W., 2014. VOLUME.03.N0.02.TAHUN 2014 / Articles. E-Jurnal Ekonomi dan Bisnis Universitas Udayana, 03(02), pp. 68-80.

Fujita, N., September 2007. Myrdal's Theory of Cumulative Causation. Evolutionary and Institutional Economics Review, 03(02), p. 275-284.

Hamid, M., Siradjudin \& Rusydi, B. U., 2017. Analisis Pertumbuhan Ekonomi Dan Ketimpangan Pendapatan Antar Kabupaten Di Provinsi Sulawesi Barat. Ecces, 04(02).

Haryono, E. \& Ilkodar, S., 2005. Menulis Skripsi. Yogyakarta: Pustaka Pelajar.

Iskandara, A. \& Saragih, R., 2018. Analisis Kondisi Kesenjangan Ekonomi Daerah: Studi Kasus Kabupaten/Kota Di Sulawesi Selatan. Jurnal Info Artha, 02(01), pp. 37-52.

Hadiz, V. R., 2004. Decentralization and Democracy in Indonesia: A Critique of NeoInstitutionalist Perspectives. Development and Change, 35(4), p. 697-718.

2010. Localizaing Power in Post-Authoritarian Indonesia. Stanford,CA: Stanford University Press.

Holzhacker, R., Wittek, R. \& Woltjer, J., 2016. Decentralization and Governance in Indonesia. Heidelberg: Springer.

Jonathan , M., 2014. People-Centred Development. In: M. Steger, P. Battersby \& J. Sira, eds. The SAGE Handbook of Globalization. Thousand Oaks, CA: Sage, pp. 902-918.

Kabul, M. A. \& Trigunarso, S. I., 2017. Perencanaan Pembangunan Daerah. Depok: Kencana. Kahin, G. \& Kahin, A., 1997. Subversi Sebagai Politik Luar Negeri. Jakarta: Pustaka Grafiti. Kementerian Perencanaan Pembangunan Nasional/Badan Perencanaan Pembangunan Nasional, 2017. Prakarsa Pemerintah Daerah Dalam Upaya Pengurangan Kesenjangan Wilayah Dan Pembangunan Daerah. Jakarta: Kementerian Perencanaan Pembangunan Nasional/Badan Perencanaan Pembangunan Nasional.

Kompas.com, 2017. KKP Dorong Ekonomi Berbasis Perikanan di Sulbar. [Online] Available at: https://ekonomi.kompas.com/read/2017/08/03/103225626/kkpdorong-ekonomi-berbasis-perikanan-di-sulbar?page=all

[Diakses 1512 2019].

Kominfo

Sulbar,

2017.

Sulawesi

Barat.

[Online]

Available at:

berita.sulbarprov.go.id/index.php/blog/sulawesi-barat

[Diakses 1512 2019].

Kurniawan, E. B., 2017. Kesenjangan Wilayah di Indonesia Kontemporer. In: R. Madinier, ed. Revolusi Tak Kunjung Selesai: Potret Indonesia Masa Kini. Jakarta: Irasec \& KPG, pp. 63-79. 
Mietzner, M., 2014. Indonesia's Decentralization: The Rise of Local Identities and Survival of the Nation States. In: H. Hill, ed. Regional Dynamics in Decentralized Indonesia. Singapura: ISEAS, pp. 45-67.

MedanBisnisDaily, 2017. Potensi Perikanan Sulawesi Barat Luar Biasa Besar. [Online] Available

http://www.medanbisnisdaily.com/news/read/2017/08/03/313395/potensi_perika $\underline{\text { nan_sulawesi_barat_luar_biasa_besar/ }}$

[Diakses 1412 2019].

Pratikno, 2001. Exercising Freedom: Local Autonomy and Democracy in Indonesia, 19992001. In: M. Erb \& P. Sulistiyanto, eds. Regionalism in Post-Suharto Indonesia. London: RoutledgeCurzon.

Rasyid, M. R., 2004. Regional Autonomy and Local Politics in Indonesia. In: E. Aspinall \& G. Fealy, eds. Local Power and Local Politics in Indonesia: Decentralisation and Democratisation. Singapura: ISEAS.

Ratnasari, Y. \& Santoso, E. B., 2014. Penentuan Tipologi Kesenjangan Wilayah di Kabupaten Lamongan Berdasarkan Aspek Ekonomi dan Sosial. Jurnal Teknik Pomits, 03(02), pp. 125130.

Samuelson, P. \& Nordhaus, W., 2010. Economics. New York: McGraw-Hill.

Yusuf, M., 2017. Metode Penelitian. Jakarta: Kencana.

Zainal, A., 2013. Model Pengelolaan Perikanan Tangkap Berkelanjutan di Sulawesi Selatan, Bogor: Sekolah Pascasarjana IPB. 